\title{
Molecular Spectroscopy Study of Human Tooth Tissues Affected by High Dose of External lonizing Radiation (Caused by Nuclear Catastrophe of Chernobyl Plant)
}

\author{
L. A. Darchuk ${ }^{1}$, L. V. Zaverbna², \\ A. Worobiec ${ }^{1}$ and R. Van Grieken ${ }^{1}$ \\ 1 University of Antwerp, Antwerp, \\ ${ }^{2}$ National University of Medicine, Lviv, \\ ${ }^{1 B}$ Belgium \\ 2Ukraine
}

\section{Introduction}

Ionizing radiation remains the most significant environmental factor, causing severe impacts on human health on the vast territory of Ukraine for 25 years.

Medical monitoring of the dental health of more than 1500 people who participated in cleaning work at the Chernobyl power station territory after the catastrophe has demonstrated an increasing of specific dental problems occurred after several years of participating at these works (Leus et al., 1998). The high level of hyperstenzy of hard dental tissues, the increase of enamel abrasion (first and second degrees) and the noncarious dental disease (cuneiform defects, pitting) are typical for around $63 \%, 36 \%$ and $47 \%$ of examined patients, respectively (Darchuk et al., 2008). Pathological dental abrasion, cuneiform defects, enamel erosion and enamel scissuras have been shown in Fig.1. Significant damages of parodontium (level II-III) by generalized severe periodontitis were detected for men with an acute radiation syndrome (Revenok, 1998). The main pathology was an intensified degeneration process while carious changes occurred, although these last were not directly related to irradiation.

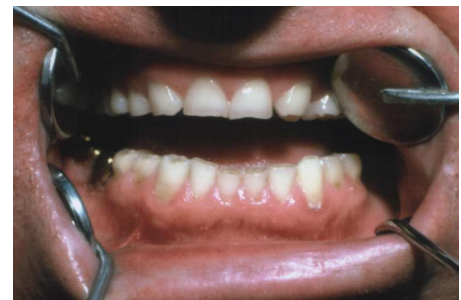

Pathological dental abrasion

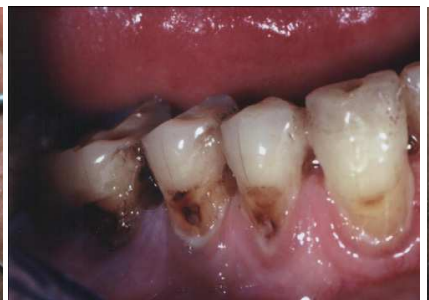

Cuneiform defects, noncaries changes

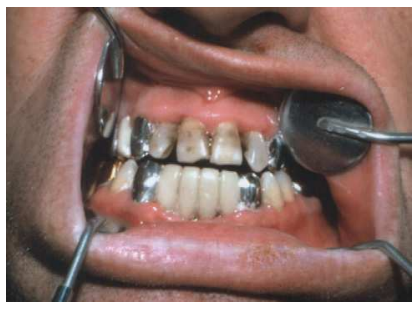

Enamel erosion

Fig. 1. Dental defects which are typical of person undergone external ionizing radiation. 
The influence of external ionizing radiation on dental tissues was analyzed by several scientists. Zhang et al. (2004) studied with SEM (Scanning Electron Microscopy) the effect of irradiation on the susceptibility of radiation caries, the structures of rats` tooth enamel and dentin. The collagen fibers and the resistance to acid after undergo external radiation were also investigated. Enamel structure changes were found after irradiation of $30-70 \mathrm{~Gy}$. It was shown that dentin morphology changed, some collagen fibers vanished and resistance to acid was reduced after irradiation.

A study on the possibility of dose-dependent tooth-germ (for four-week-old dogs) damage produced by ionizing radiation has shown hyperemia and edemata on tooth-germ pulps from 1.3 Gy onward. Both of these dental diseases became more acute as the radiation dose increased from 1.3 Gy to $5.3 \mathrm{~Gy}$. Possible damage to both the dentin and enamel was pointed out (Sobkoviak et al., 1977).

Dental analysis of rats which had undergone an exposure to 13.2 Gy during 100 days showed a temporary halting in tooth formation following exposure. The dentin which was formed immediately after the radiation was architecturally disarranged to the extent that no paralleling of dentinal tubules existed. In some instances, there was actual resorption of tooth structure with a fibrous replacement (English et al., 1954).

The goal of this work was to study structural changes of teeth taken from people which were exposed to high doses of external ionizing radiation. They worked for different periods: from several weeks to several months, on the territory of the Chernobyl reactor IV zone during the first year just after the catastrophe. The teeth were extracted according to medical recommendations because of oral surgery or mechanical damage due to accidents.

Infrared (IR) absorption and micro-Raman spectroscopy (MRS) as the most efficient techniques to analyze molecular structure of biological tissues (Ellis et al., 2006) have been applied to investigate tooth tissues. The main advantage of Infrared spectroscopy is a superior signal-to noise ratio, which is much less for Raman spectroscopy. Anyway Raman spectroscopy offers another benefit. The MRS is very useful for analysis of bone-like objects, which consist of mineral and organic substances, because Raman vibrational bands of crystalline materials are often sharp. So that the vibrational bands typical of organic matrix are more distinguishable and the identification of minerals is less doubtful.

Enamel, dentin, and cement belonging to 17 patients who absorbed high doses (0.5-1.7 Gy, high dose group, HDG) of ionizing radiation were studied. Only patients without the bone marrow affection were investigated. For comparison the same tooth tissues of 10 men who had not been exposed to radiation (control group, CG)) were investigated as well.

Tooth is composed by enamel, dentin, cement and root (Fig. 2) which are bioinorganic materials. The organic part of the dental tissues is represented by collagen (Ten Gate, 1998) which controls the calcification of bone and crystallization of apatite in bones (Castrom et al., 1956). Collagen is rich in glycine, proline, and hydroxyproline. Collagen molecules are composed by 3 polypeptide chains forming tubinal structure. Collagen is rich with glycine, praline and hydroxyproline (Neuberger, 1956). The composition of aminoacids depends on the dental tissues - the ratio of proline:hydroxyproline:glycine is about 11:11:55 for dental enamel and 29:21:62 for dentin (Geller, 1958). The mineral part of enamel, dentin and cement is composed by carbonate hydroxyapatite, with an approximate formula $\mathrm{Ca}_{10}\left(\mathrm{PO}_{4}\right)_{6-x}(\mathrm{OH})_{2-}$ $y\left(\mathrm{CO}_{3}\right)_{x+y}$, where $0 \leq x \leq 6$ and $0 \leq \mathrm{y} \leq 2$ (Le Geros, 1991). The carbonate ion $\mathrm{CO}_{3}{ }^{2-}$ can substitute for either $\mathrm{PO}_{4}^{3-}$ (B-substitution, a $\mathrm{CO}_{3}^{2-}$ ion substitutes for a single $\mathrm{PO}_{4}^{3-}$ ion) or $\mathrm{OH}^{-}(\mathrm{A}-$ substitution, a $\mathrm{CO}_{3}{ }^{2-}$ ion replaces two $\mathrm{OH}^{-}$ions) (Le Geros, 1981; Elliott, 1994). Also the carbonate ion can be present in dental tissues as an adsorbed phase in the mineral lattice (Elliott, 1994). 


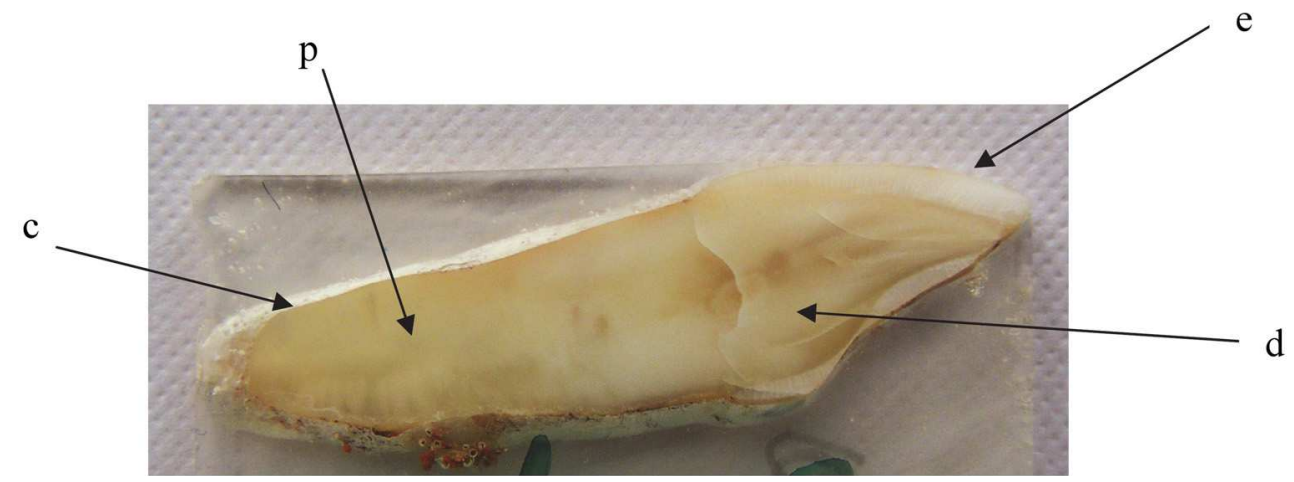

Fig. 2. Cross section of a tooth; e, enamel; $d$, dentin; c, cement; $p$, pulp cavity.

Tooth enamel, covering tooth external surface, is the hardest and most mineralized dental tissue. It contains about $96-98 \mathrm{wt} . \%$ of mineral matrix and around $2-4 \mathrm{wt}$. $\%$ of protein and water. Protein is rich in proline, glycine and glutamic acid.

Dentin makes up the bulk of the tooth and it is surrounded by cement at the root and by a thin protective layer of enamel. Dentin consists of about $70 \mathrm{wt} \%$ of mineral matter, $20 \mathrm{wt} . \%$ of organic materials, and $10 \mathrm{wt.} \%$ of water (Ten Gate, 1998). The protein of dentin is composed mainly of Type I collagen and non-collagenous proteins (Le Geros, 1981; 1991).

Cement is a bonelike calcified connective tissue covering tooth roots (Ross et al., 2003) and its composition is similar to the composition of dentin. Cement consists of about 60-65 wt. $\%$ of mineral matter, around 23-26 wt.\% of organic compounds (mainly collage) and about 12 wt. $\%$ of water.

Diversities of enamel, dentin and cement are provided by the nature of the tissues embryogenesis. The tooth dentin and cement are grown up from mesenchyme while the tooth enamel is grown up from ectoderm, so that enamel almost does not consist of organic matrix.

\section{Samples and experimental technique}

\subsection{Infrared absorption spectroscopy}

The preparation of samples for infrared spectroscopy has some features because biological tissues consist of some amount of water. So that samples are dried to avoid overlapping of absorption bands arose from analyzed objects with a broad absorption bands typical of water.

For preparing samples teeth were washed with distilled water and then left for several hours in a drying chamber at 50 $\mathrm{C}$. Afterwards enamel, dentin and cement were sawn down with diamond dental drill to get powder of tooth tissues for IR spectral analysis. Then $0.2 \mathrm{~g}$ of tooth tissue powder was thoroughly mixed with $50 \mu \mathrm{l}$ vaseline oil and put in a cuvette of KBr.

All IR spectra were recorded with one-beam infrared spectrometer IKS-31. Ten accumulations of spectra has been applied for each measurement to improve signal-to-noise ratio. Infrared spectral analysis was done in a low vacuum camera $\left(10^{-1} \mathrm{~Pa}\right)$ to minimize overlapping with broad absorption bands typical of atmospheric $\mathrm{CO}_{2}$ and $\mathrm{H}_{2} \mathrm{O}$. The infrared intensity transmitted by the cuvette containing the sample $\left(\mathrm{I}_{\mathrm{s}}\right)$ and that transmitted by an empty cuvette $\left(I_{0}\right)$ were measured in the $600-4000 \mathrm{~cm}^{-1}$ spectral range with a resolution of $2-4 \mathrm{~cm}^{-1}$. The spectral resolution depends on diffraction grate (number of grating groove per $\mathrm{mm}$ ) applied for each spectral interval. 
The absorption intensity $\mathrm{I}_{\mathrm{a}}(\mathrm{v})$, where $\mathrm{v}$ is wavenumber in $\mathrm{cm}^{-1}$, of the investigated samples was obtained as $I_{a}=\left(1-I_{s} / I_{c}\right)$, which is approximately proportional to the sample absorption. For a semiquantitative analysis, the $\mathrm{I}_{\mathrm{a}}(\mathrm{v})$ spectra were fitted using a standard procedure which describes the $\mathrm{I}_{\mathrm{a}}(\mathrm{v})$ spectrum as a sum of Lorentzian components (Burn, 1985).

\subsection{Micro-Raman spectroscopy}

For micro-Raman spectroscopy washed and dried teeth were put in polymer solution of Technoviz 4004 (Kulzer, Germany), which got solidified after 6-8 hours. Then the tooth samples were cut in slices with a thickness of $1 \div 1.5 \mathrm{~mm}$ with a diamond disk, Fig. 2 .

Raman spectra have been collected with a Renishaw InVia micro-Raman (Renishaw plc, GB) spectrometer. For vibrational excitation two laser were applied: argon laser $(514.5 \mathrm{~nm}$, Spectra Physica) with a maximum laser power of $50 \mathrm{~mW}$ as well as a diode laser $(785 \mathrm{~nm}$, Renishaw) with a maximum laser power of $300 \mathrm{~mW}$. Raman spectra were obtained in the spectral range $100-3200 \mathrm{~cm}^{-1}$ at a resolution of $2 \mathrm{~cm}^{-1}$. Measurement times between 10 and $30 \mathrm{~s}$ have been used to collect the Raman spectra with a signal-to-noise ratio of better than $100 / 1$.

The slices of tooth were placed on the stage of the microscope, and the transverse cross section was oriented perpendicularly to the incident laser beam. A continuous laser beam was focused on a sample via 50x and 100x microscope objectives. The laser beam spot size depends on objectives. Spectra were obtained using a $100 \times(\mathrm{NA}=0.95$; theoretical spot size of $0.36 \mu \mathrm{m}$ and $0.50 \mu \mathrm{m}$ for $514.5 \mathrm{~nm}$ and for $785 \mathrm{~nm}$ laser, respectively) and $50 \times(\mathrm{NA}=0.70$; theoretical spot size of $0.45 \mu \mathrm{m}$ and $0.68 \mu \mathrm{m}$ for $514.5 \mathrm{~nm}$ and for $785 \mathrm{~nm}$ laser, respectively) magnification objectives.

Because of the heterogeneous nature of teeth, single point Raman microspectroscopy cannot adequately describe the microstructure of tissues and therefore spatial information is needed. Hence for the analysis of teeth, MRS mapping, with a spatial resolution of $\sim 1 \mu \mathrm{m}$, allows to analyze tooth tissue zones such as individual cement lines, individual lamellae. Raman spectral mapping was employed to study the orientation of mineral and collagen components of bone tissues by Morris et al. (2004) and by Kazanci et al. (2006).

A computer controlled micro-Raman mapping was applied to analyze enamel, dentin, and cement. The microscope stage was XY-motorized and computer-controlled for point-by-point scanning with $0.1 \mu \mathrm{m}$ resolution, $1 \mu \mathrm{m}$ reproducibility and $90 \mathrm{~mm} \times 60 \mathrm{~mm}$ maximum spatial range. Raman mapping data sets are collected by point-by-point scanning with $1 \mu \mathrm{m}$ as a minimum step. A total of 20 images were obtained by using the motorized translation stage and the pixel reconstruction. Raman images were acquired in different rectangular areas of $60 \times 60,60 \times 40,50 \times 50,50 \times 30$ and $40 \times 30 \mu \mathrm{m}^{2}$. The images were created with step size of 1 or $2 \mu \mathrm{m}$. The sample background fluorescence was subtracted with Wire 2.0 softwear (Renishaw, GB). The Raman spectra, except MRS mapping, were normalized to the intensity of the strongest band at $962 \mathrm{~cm}^{-1}\left(\mathrm{v}_{1}-\mathrm{PO}_{4}\right.$ mode $)$ of each spectrum.

\section{Discussion}

\subsection{Enamel}

Mineral component of dental tissues causes the presence in the IR spectra of bands assigned to the carbonate-ions $\left(\mathrm{CO}_{3}^{2-}\right)$ and the orthophosphate-ions $\left(\mathrm{PO}_{4}^{3-}\right)$. Collagen is presented by amide groups of proteins - $\left(\mathrm{CONH}_{2}\right)$. The amide absorption bands are well evident at 1660 $\mathrm{cm}^{-1}$ (amide I), $1540-1550 \mathrm{~cm}^{-1}$ (amide II), and band at $1240 \mathrm{~cm}^{-1}$ (amide III). 
Infrared spectra of dental enamel taken from patients of both HDG and CG consisted of strong and wide absorption band at $900-1200 \mathrm{~cm}^{-1}$ which arose due to $\mathrm{v}_{3}$ vibration mode of the phosphate-ion $\mathrm{PO}_{4}^{3-}$ (Fig. 3). This wide absorption band consisted of a set of bands at 950-970, 1000-1020, and 1050-1080 $\mathrm{cm}^{-1}$ in the IR spectra of enamel. A comparison of IR spectra of enamel belonging to patients from the control group and people exposed to high doses of ionizing radiation did not show significant changes of absorption band profile typical of phosphate-ion. Nevertheless it was detected that the intensity of the absorption band at $880 \mathrm{~cm}^{-1}$ which is typical for $\mathrm{CO}_{3}^{2-}$ ions was stronger in the spectra of irradiated enamel. So that the phosphate-carbon ratio in mineral matrix of enamel changed to increasing of carbonate content in enamel belonging to patients of HDG. Semiquantitative analysis was applied to estimate the area of the band assigned to the carbonate-ions. The area of the band was calculated with Origin softwear according to a procedure described by Burn (1985) and Bebeshko et al. (1998). This analysis showed increasing of the area of the band typical of the anion $\mathrm{CO}_{3}^{2-}$ (at $880 \mathrm{~cm}^{-1}$ ) up to $0.98 \pm 0.04$ (a.u.) for people from HDG, in comparison with the area value of $0.84 \pm 0.04$ (a.u.) for patients of CG. Absorption bands at 1420 and $1482 \mathrm{~cm}^{-1}$ arose from the $\mathrm{v}_{3}-\mathrm{CO}_{3}{ }^{2-}$ vibration mode were not distinguished in the obtained IR spectra, because of their overlapping with the strong absorption band at 1440 $\mathrm{cm}^{-1}$ typical of vaseline.

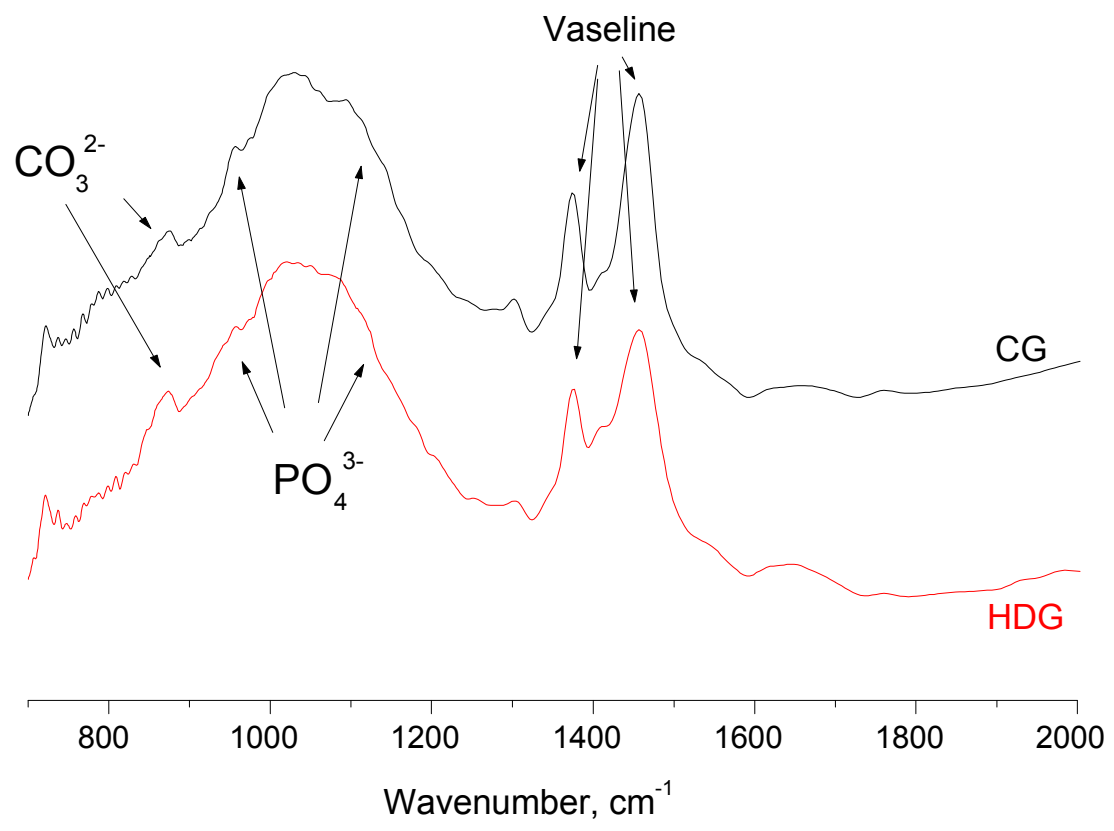

Fig. 3. Infrared spectra of enamel taken from patients exposed to high doses of ionizing radiation (HDG) and people from control group (CG).

Raman spectra of teeth enamel of HDG and CG were more informative than infrared spectra to detect transformations of the enamel mineral matrix. The Raman spectra of enamel obtained with $514 \mathrm{~nm}$ were as informative as those obtained with $785 \mathrm{~nm}$ laser beam excitation (Fig. 4), but the spectra with excitation at $514 \mathrm{~nm}$ often showed an intensive 
fluorescence background. The fluorescence should be easily subtracted, but if the fluorescence is huge and the intensity of Raman bands is very low compared to the fluorescence signal, the accuracy of analysis will be lower.

Hydroxyapatite single crystals belong to the crystal-class $\mathrm{C}_{6}$ and they can be described with the Raman-active symmetry tensors $\left(\mathrm{A}, \mathrm{E}_{1}\right.$, and $\left.\mathrm{E}_{2}\right)$. The free $\mathrm{PO}_{4}{ }^{3-}$ ion has four internal vibration modes: $\mathrm{v}_{1}$ at 948 and $962 \mathrm{~cm}^{-1}, \mathrm{v}_{2}$ at 432 and $447 \mathrm{~cm}^{-1}, \mathrm{v}_{3}$ at 1028, 1053 and $1075 \mathrm{~cm}^{-1}$, and $\mathrm{v}_{4}$ at 580, 593 and $608 \mathrm{~cm}^{-1}$ (Fig. 4). Intensities of the Raman bands are invariant to the orientation of the crystal and depend only on the c-axis orientation (Tsuda et al., 1994; Nelson et al., 1982).

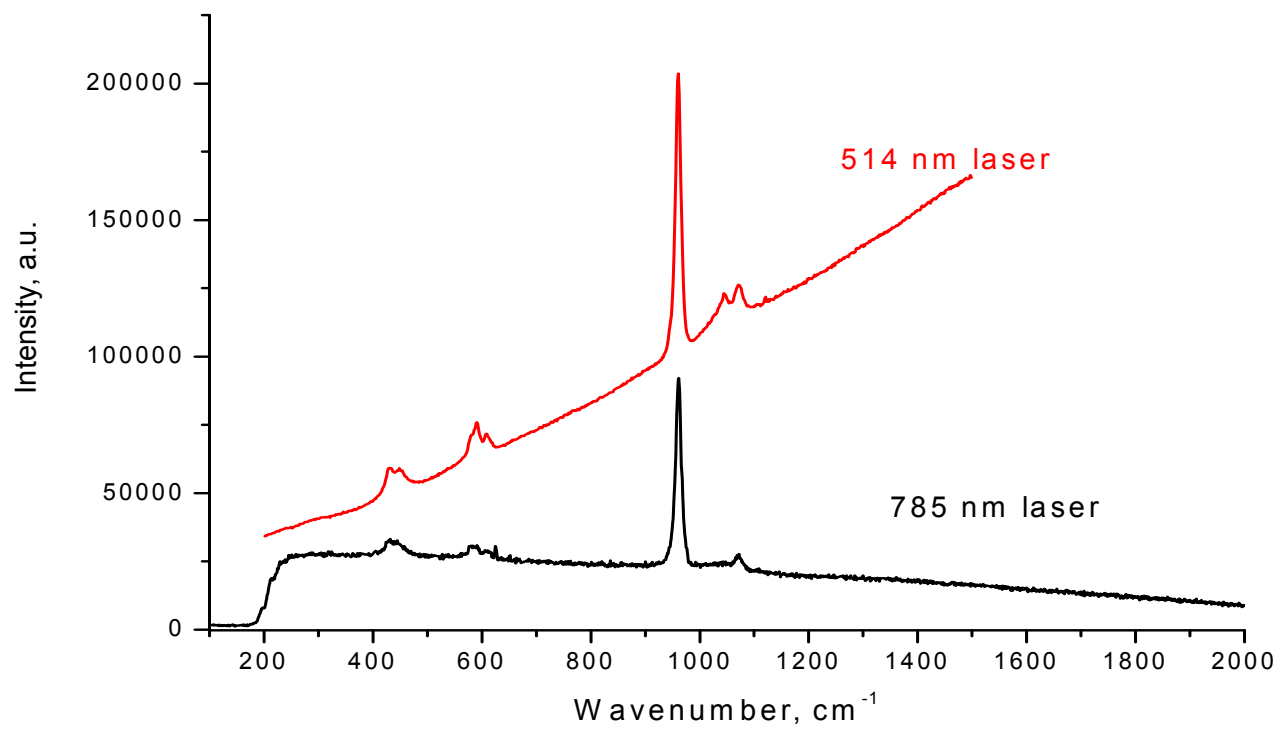

Fig. 4. Raman spectra of enamel recorded with laser beam excitation at $514 \mathrm{~nm}$ and at $785 \mathrm{~nm}$.

In the case of enamel taken from patients exposed to ionizing radiation: for the $\mathrm{v}_{4}$ vibration mode of $\mathrm{PO}_{4}{ }^{3-}$, the band at $580 \mathrm{~cm}^{-1}$ was not detected, the band at 450 and $608 \mathrm{~cm}^{-1}$ became very weak, but the band at $593 \mathrm{~cm}^{-1}$ did not change (Fig. 5) in comparison with the Raman spectra of enamel belonging to men from control group. These results can be explained as a breaking of the hydroxyapatite crystal symmetry.

The shoulder at $1028 \mathrm{~cm}^{-1}\left(\mathrm{v}_{3}\left(\mathrm{PO}_{4}\right)\right)$ was covered by a weak band at $1045 \mathrm{~cm}^{-1}\left(\mathrm{v}_{3}\left(\mathrm{PO}_{4}\right)\right.$, out of plane), which is typical of amorphous phosphate and a weak band at $1071 \mathrm{~cm}^{-1}$ (Fig. 5) which is assigned to carbonated apatite, type-B substitution (Elliott, 1994; Morris et al., 2004).

The increase of the carbonate content in the enamel is the result of a lack of equilibrium between phosphate and carbonate phases of $\mathrm{Ca}_{10}\left(\mathrm{PO}_{4}\right)_{6-x}(\mathrm{OH})_{2-y}\left(\mathrm{CO}_{3}\right)_{x+y}$, induced by irradiation. The mentioned changes of the mineral matrix lead to a decrease of tooth enamel hardness. 

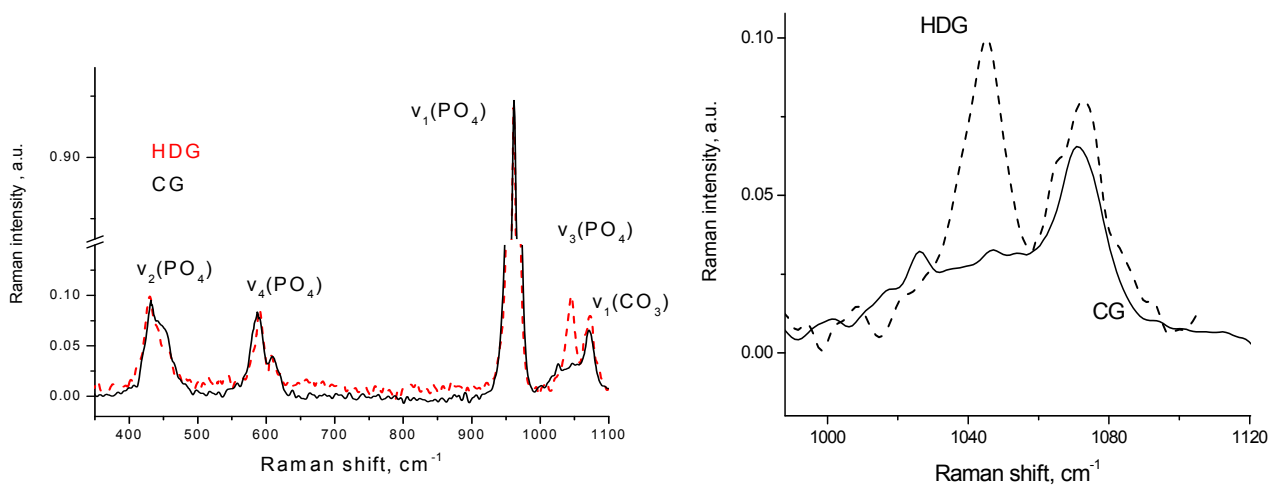

Fig. 5. Raman spectra in the range of internal vibrations of the mineral part of tooth enamel taken from patients of HDG and CG.

\subsection{Dentin and cement}

Dentin and cement differ from enamel and they look like coarse-fibered bone. IR spectra of dentin and cement were very similar; so only infrared absorption spectra of dentin will be discussed. Infrared spectroscopy of both dentin and cement taken from patients of HDG showed a decreasing content of the mineral matrix (intensities of phosphate bands are lower that those for CG) and changes in organic matrix (Fig. 6). The area of the absorption band at $880 \mathrm{~cm}^{-1}$, typical of the anion $\mathrm{CO}_{3}{ }^{2-}$ increased from $0.97 \pm 0.05$ (a.u.) for dentin taken from people of control group to $1.05 \pm 0.05$ (a.u.) for HDG. The absorption band of

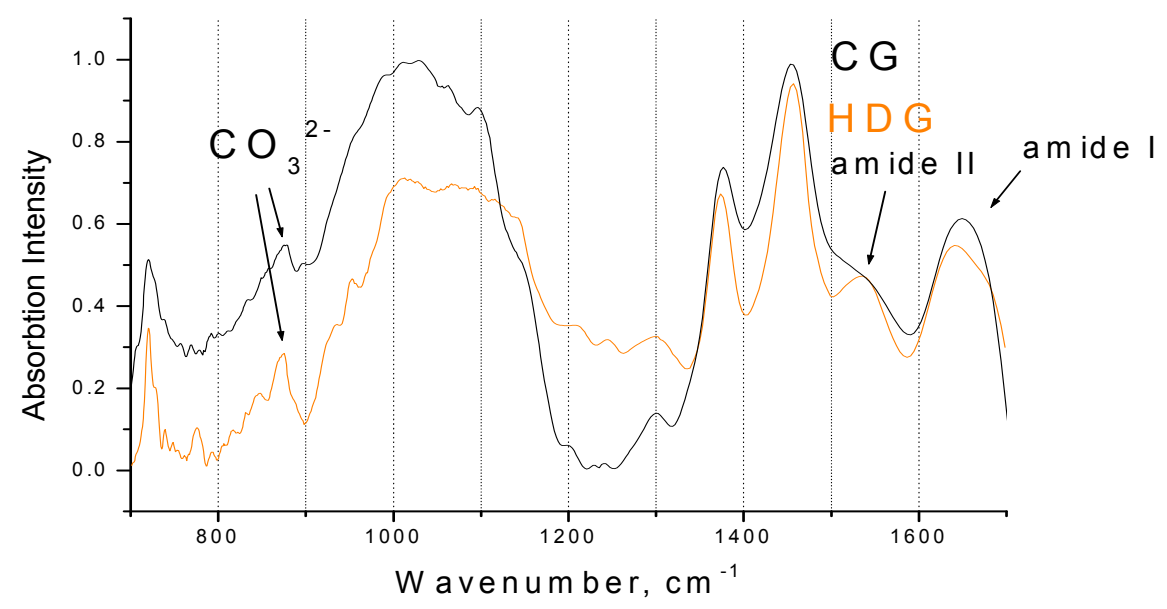

Fig. 6. Infrared spectra of dentin for patients exposed to a high doses of radiation (HDG) and people from control group (CG). 
the amide III at $1240 \mathrm{~cm}^{-1}$ and amide II at $1550 \mathrm{~cm}^{-1}$ partly overlapped with strong absorption bands at 1380 and $1440 \mathrm{~cm}^{-1}$ assigned to vaseline oil, so that it was complicated to provide a semiquatitative analysis of areas of the bands assigned to amides. Anyway, reduction of the ratio between amide I and amide II amount was detected - ratio of amide I to amide II bands` area changed from $1.5 \pm 0.05$ (a.u.) for CG to $1.2 \pm 0.05$ (a.u.) for HDG. These changes of organic matter were the results of the collagen structure degradation caused by high doses of external radiation.

It can be seen in Fig. 7 that the Raman spectra of dentin and cement were also very similar: therefore mainly Raman spectra of dentin will be discussed.

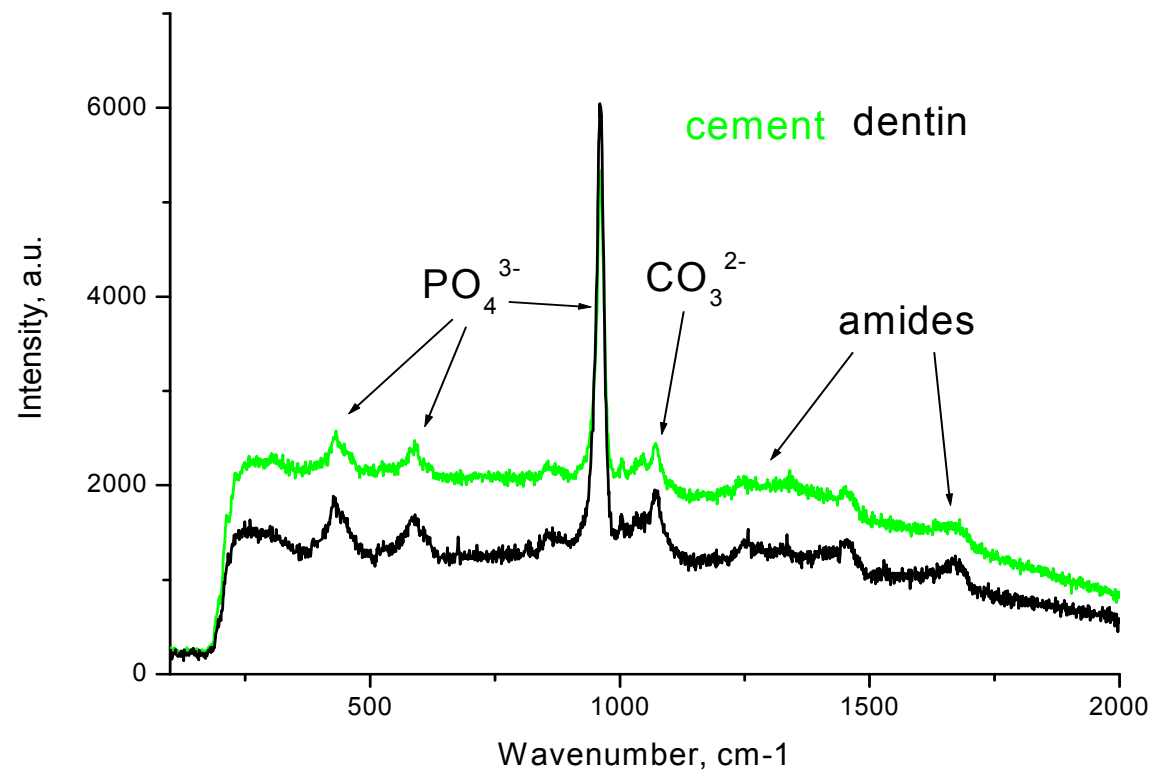

Fig. 7. Raman spectra of dentin and cement (control group) was recorded with $785 \mathrm{~nm}$ laser beam excitation.

In order to detect changes of the mineral matrix caused by high doses of external ionizing radiation, the full width at half maximum (FWHM) of the strongest band (at $\left.961 \mathrm{~cm}^{-1}\right)$ assigned to phosphate-ion has been estimated for both HDG and CG. FWHM bandwidth and area $\mathrm{S}$ of the $\mathrm{PO}_{4}{ }^{3-} \mathrm{v}_{1}$ band were determined by curve of it with the procedure describing by Burn, (1985) and Bebeshko et al. (1998). It was found that the band could be well fitted with two Lorentian peaks at $955 \mathrm{~cm}^{-1}$ and $962 \mathrm{~cm}^{-1}$ (Table 1)

\begin{tabular}{|c|c|c|c|c|}
\hline Center of peaks & \multicolumn{2}{|c|}{$955 \mathrm{~cm}^{-1}$} & \multicolumn{2}{c|}{$962 \mathrm{~cm}^{-1}$} \\
\hline & FWHM (cm-1) & S (a.u.) & FWHM (cm-1) & S (a.u.) \\
\hline Control group & 18.1 & 29630 & 11.3 & 78210 \\
\hline High doses radiation group & 18.3 & 37232 & 11.5 & 76138 \\
\hline
\end{tabular}

Table 1. FWHM and area of the strongest band at $961 \mathrm{~cm}^{-1}$ calculated from Raman spectra of dentin belonging to HDG and CG patients 
The extra peak at $955 \mathrm{~cm}^{-1}$ had to be involved into the calculation to curve the strong phosphate band and it is an additional $\mathrm{v}_{1}$ peak assigned as amorphous or crystallographically disordered hydroxyapatite (Marcovich et al., 2004). For HDG this disordering is high and the area of the main peak at $962 \mathrm{~cm}^{-1}$ is less, this could be caused by ionizing radiation. For instance, the strongest band of the $\mathrm{PO}_{4}^{3-}$ in Raman spectra of both CG and HDG could be curved with only one peak at $961 \mathrm{~cm}^{-1}$ with FWHM of $10.1 \mathrm{~cm}^{-1}$, so that crystallography of hydroxyapatite in enamel was less sensitive to high doses ionizing radiation.

The Raman spectra of dentin belonging to patients from HDG showed slight increase of the band at $1071 \mathrm{~cm}^{-1}\left(\mathrm{v}_{1}\left(\mathrm{CO}_{3}^{2-}\right)\right.$ mode) which could be explained by substitution of the phosphate ion with carbonate (B-type substitution), Fig. 8.

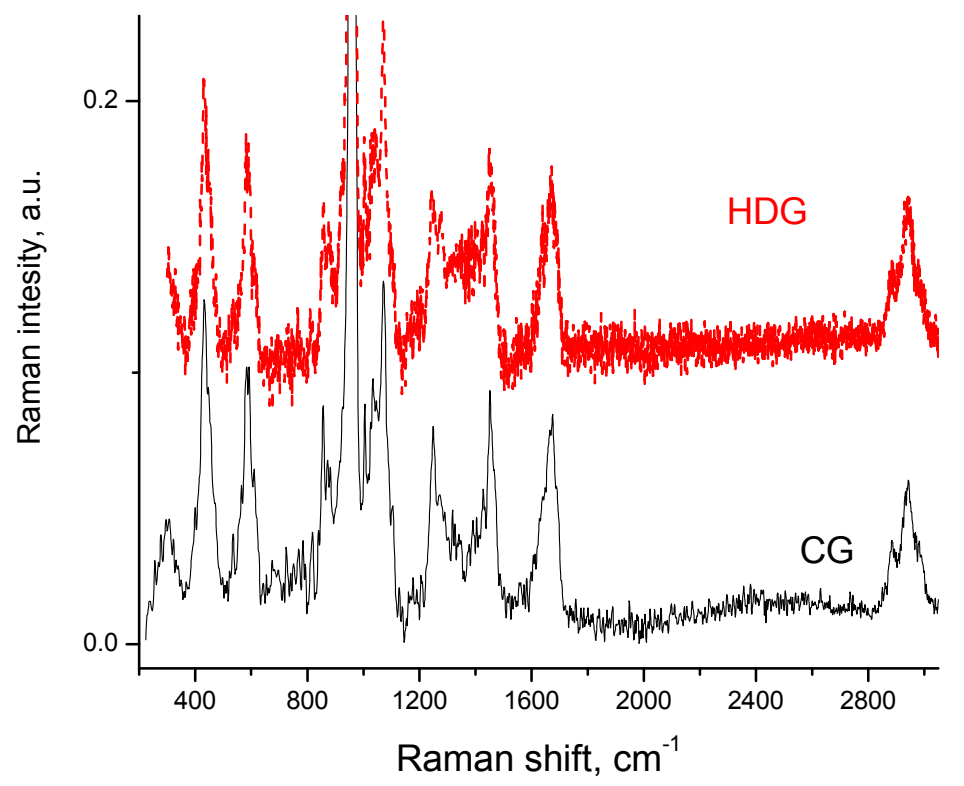

Fig. 8. Raman spectra of dentin taken from patients of HDG and CG.

The feature of dentin organic matrix is the presence of osteonectin which links the bone mineral (hydroxyapatite) and the collagen phases. Osteonectin is a specific noncollagenous protein and consists of two amino acids: glutamine $\left(\mathrm{R}=-\mathrm{CH}_{2}-\mathrm{CH}_{2}-\mathrm{CO}-\mathrm{NH}_{2}\right)$ and phenylalanine $\left(\mathrm{R}=-\mathrm{CH}_{2}-\mathrm{C}_{6} \mathrm{H}_{5}\right)$. The band at $1004 \mathrm{~cm}^{-1}$ assigned to phenylalanine was observed in the Raman spectra of the dentine from patients of HDG and CG (Fig. 9). According to the Raman spectra of dentin taken from HDG, phenylalanine is affected by external ionizing radiation as shown by the band at $1004 \mathrm{~cm}^{-1}$ that splits into two narrow bands. The intensities of the bands typical of glutamine (at $815 \mathrm{~cm}^{-1}$ and $1330 \mathrm{~cm}^{-1}$ ) were significantly lower in case of the HDG, which can be ascribed to the ionizing radiation influence. These results have shown a sensitivity of osteonectin to high doses of external radiation. 


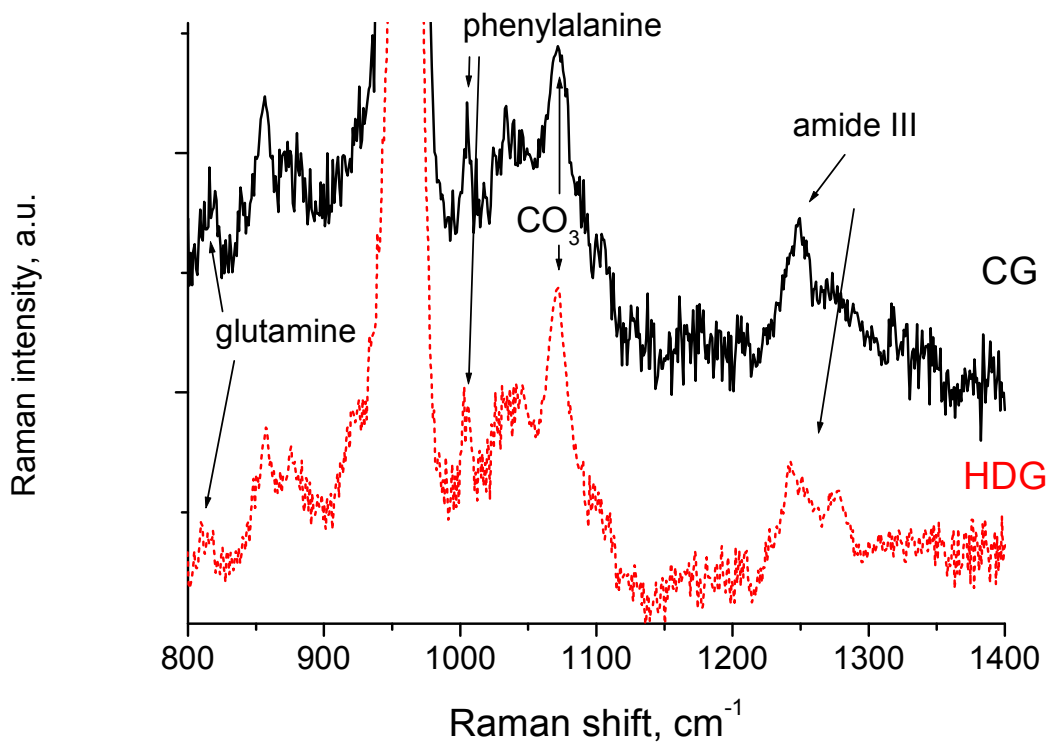

Fig. 9. Raman spectra of dentin taken from patients of HDG and CG in spectral region of osteonectin.

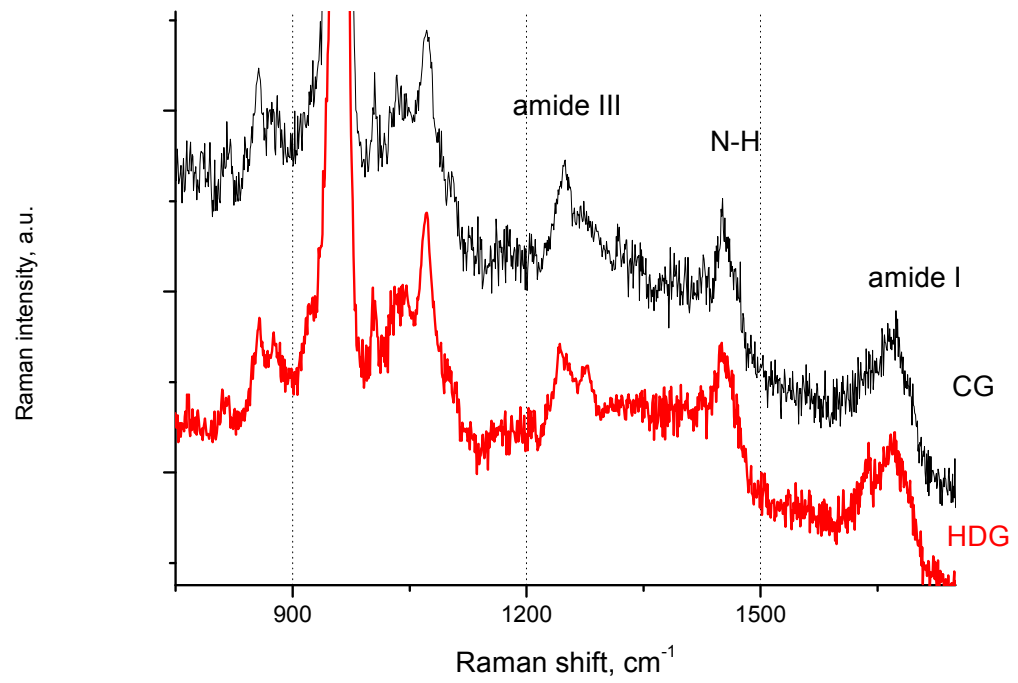

Fig. 10. Raman spectra of dentin belonging to patients of HDG and CG in spectral region of proteins. 
The amide absorption bands are well evident in the Raman spectra at $1670 \mathrm{~cm}^{-1}$ (amide I) and at $1240 \mathrm{~cm}^{-1}$ (amide III) for both CG and HDG. A strong impact of high doses of ionizing radiation on the amide part of dentin and cement has been demonstrated by changes of amides` bands (Fig.10).

The wide band corresponding to amide I vibrations of collagen (peptide carbonyl coupled to the NH-out-of-plane band) is weakly structured with a main wide line at about $1670 \mathrm{~cm}^{-1}$ (poly-L-proline) and a shoulder at $1640 \mathrm{~cm}^{-1}$ for dentin and cement from patients of CG. For dentin and cement from patients of HFG, the wide band of amide I was split into two bands at 1245 and $1270 \mathrm{~cm}^{-1}$. The split of the amide I band could be explained as breakdown of peptide bonds of collagen caused by ionizing radiation. The band at $876 \mathrm{~cm}^{-1}$ could be assigned to hydroxyproline which is an amino acid formed upon hydrolysis of connective-tissue proteins such as collagen (about 14) and elastin but rarely from other proteins.

High doses of radiation also provoked decreasing intensities of the hydroxyproline band at around $855 \mathrm{~cm}^{-1}$ and the proline band at around $875 \mathrm{~cm}^{-1}$ and the proline shoulder at $920 \mathrm{~cm}^{-1}$. Changes of the proline band intensity are more significant compared to those in the hydroxyproline. Loss of nitrogen in collagen has been detected as a decreasing of the band at $1450 \mathrm{~cm}^{-1}$. The changes of Raman bands typical of organic matrix of dentin and cement reflect a degradation of the collagen structure and breaking of collagen bonds affected by high doses of radiation.

So, high doses of external ionizing radiation lead to mineral composition changes and to alteration of the organic matrix of dentin and cement.

\subsection{Mapping of dental tissues}

Micro Raman analysis offers superior spatial resolution $(0.6-1 \mu \mathrm{m})$ compared to the infrared microspectroscopy resolution which is not better than $5-10 \mu \mathrm{m}$. So that micro-Raman spectroscopy is very useful for the analysis of biological localities such as single cement lines, boundaries around microtracks, and human dentin tubules.

Micro-Raman mapping was performed for enamel, dentin and cement belonging to patients from both HDG and CG. Mapping of Raman spectra did not show any differences in spatial distribution of organic and mineral components, which could be caused by high doses of external ionizing radiation. Due to the Raman mapping it could be seen that osteonectin and amide III formed single lines (Fig. 11) which look like channels going through dental tissues, such as dentin and cement. The diameter of these lines was calculated according to the applied mapping step of $1 \mu \mathrm{m}$ and was around 3-5 $\mu \mathrm{m}$. We need to underline that the distribution of ostenectin was similar to the amide III distribution - the same location of maximum and minimum of their Raman bands intensities.

The applied mapping of dentin (from HDG) also found out several spots with size around 1 $\mu \mathrm{m}$ where the intensity of the strongest band typical of phosphate ion was incredibly low. The single Raman spectrum which was extracted from the mapping (Fig.12) showed that at this spot only organic matrix is present. The near absence of the bands typical of the phosphate-ion demonstrated disordering of the hydroxyapatite crystal. It is possible to suggest that this local resorption of mineral matrix was provoked by high doses of ionizing radiation, but only a few similar spots have been found. 


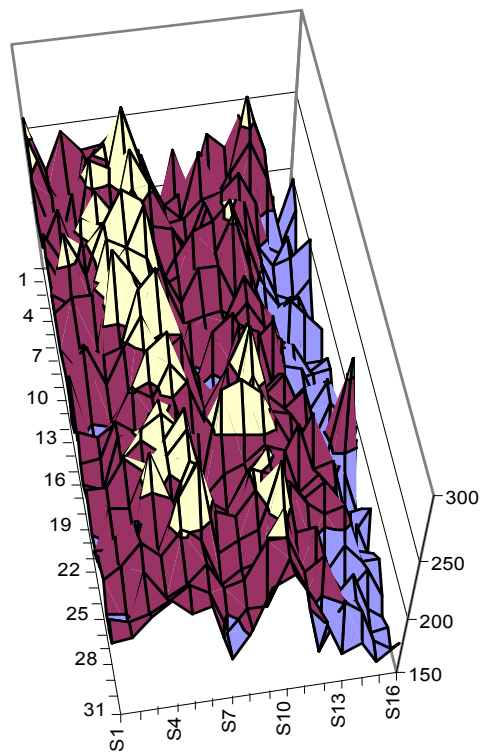

Organic matrix (according to the intensity of the band of amide III at $1260 \mathrm{~cm}^{-1}$

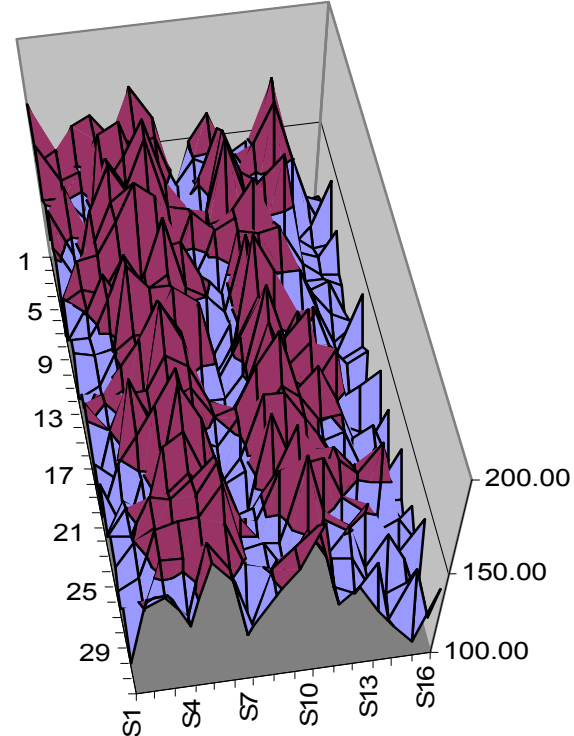

Distribution of osteonectin according to the intensity of the band at $1004 \mathrm{~cm}^{-1}$

Fig. 11. Spatial distribution of amide III and osteonectin in dentin, the mapping has been done with step of $1 \mu \mathrm{m}$.

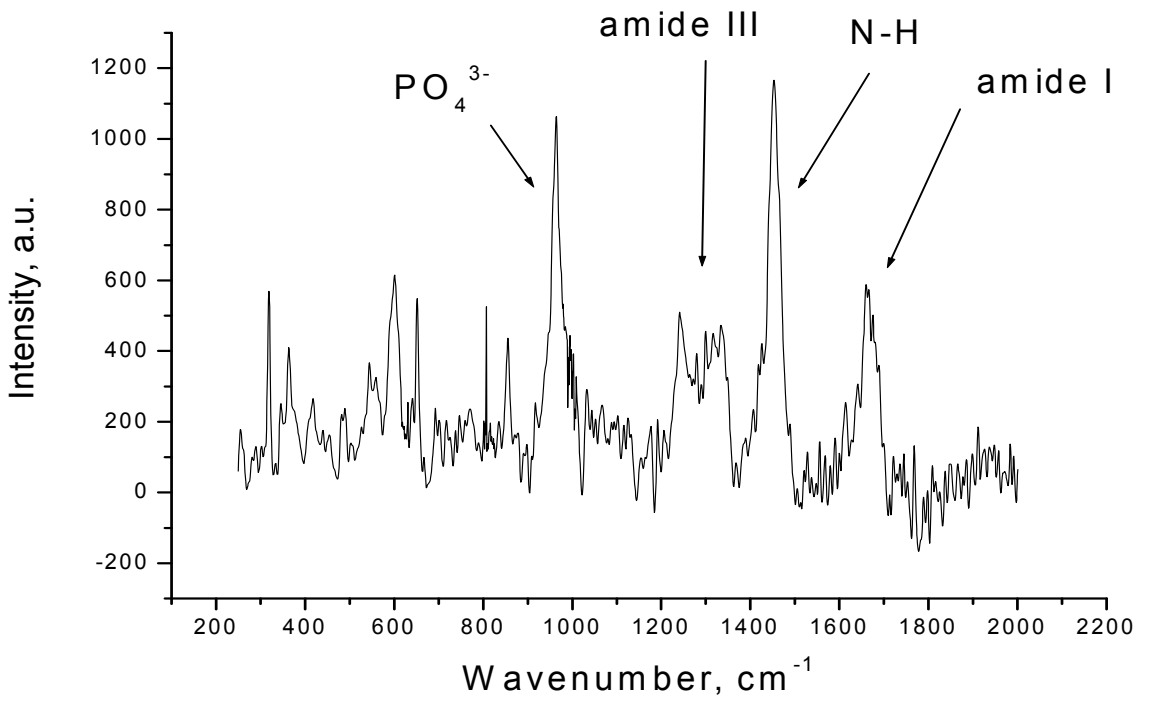

Fig. 12. Raman spectrum of resorbed area of dentin belonging to patient from HDG

Histological dentin consists of a calcified matrix with dental tubules. With Raman mapping it was demonstrated that some of these tubules go through the dentin-enamel junction and 
terminate in the enamel (Fig.12, taken from Darchuk et al., 2011). It was possible to estimate that the diameter of dentin channels was around $2 \mu \mathrm{m}$.

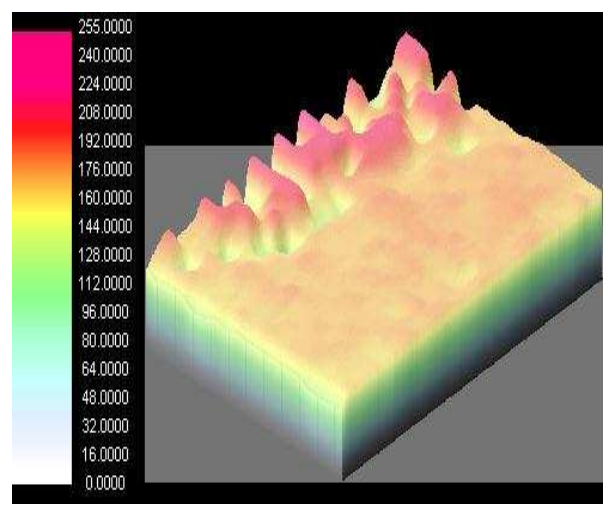

Inorganic matrix

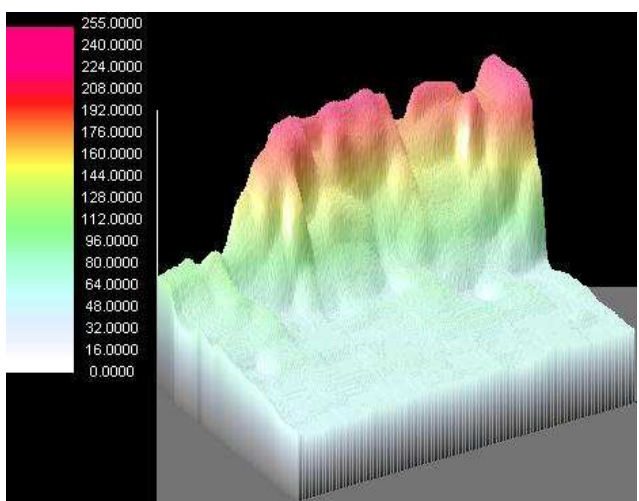

Organic matrix

Fig. 12. Spatial distribution of mineral (according to intensities of the band of hydroxyapatite at $962 \mathrm{~cm}^{-1}$ ) and organic (according to intensities of the band of amide I at $1670 \mathrm{~cm}^{-1}$ ) components on the boarder between enamel and dentin; area of mapping was $30 \times 50 \mu \mathrm{m}$.

\section{Conclusions}

Thanks to the application of two different spectroscopic analytical methods, complementary information regarding the influence of high dose radiation on the dental tissues was achieved. The results of infrared and micro-Raman spectroscopy analysis of dental tissues taken from patients of CG and HDG were in good agreement but micro-Raman spectroscopy gave a lot of details about the pathological effects of high doses of external radiation on the human dental tissues.

The changes in mineral matrix of enamel and dentin (as well as cement) were caused by substitution of the phosphate ion with the carbonate ion which lead to lack of phosphatecarbonate equilibrium. An increase of amorphous phosphates in dentin and cement showed the breakage of the hydroxyapatite crystal symmetry brought about the decrease of dental tissues hardness.

Both, infrared and Raman spectroscopy have demonstrated changes in organic structure of tooth tissues. High doses of radiation effect resulted in destruction of the collagen chain of dentin and cement: chemical transformations of amino acids, breakdown of peptide bonds of collagen and loss of nitrogen in collagen. Micro-Raman spectroscopy demonstrated sensitivity of osteonectin to high doses of external radiation. Intercrystalline voids, appeared as a result of ionizing radiation effect, have been filling with low differentiation connective tissue which could not fix hydroxyapatite crystals well enough.

\section{References}

Bebeshko V.G., Darchuk-Korovina L.A., Liashenko L.A., Sizov F.F. \& Darchuk S.D. (1998). Spectral diagnostics of the bone structure cnanges in the case of oncohematological disease and acute radiation syndrome, J. Problems Osteol. 1, 25-30 (in Russian). 
Burn G. (1985). Solid State Physics. Burlington, MA: Academic Press, New York, 755 p., ISBN13: 978-0121460709

Castrom D., Engsstrom A., \& Finean J.B. (1956). The influence of collagen on the organization of apatite crystallization in bone. Chem. Abstr. 50, $12149 \mathrm{~h}$.

Darchuk L.A., Zaverbna L.V., Bebeshko V.G., Worobiec A., Stefaniak E.A., \& R. Van Grieken. (2008). Infrared investigation of hard human teeth tissues exposed to various doses of ionizing radiation from the 1986 Chernobyl accident. SpectroscopyBiomedical Application, 22, 105-111.

Darchuk, L., Zaverbna, L., Worobiec, A., \& Van Grieken, R. (2011) Structural features of human tooth tissues affected by high dose of external ionizing radiation after nuclear catastrophe of Chernobyl plant. Microchemical Journal, 97, 282-285.

Elliott J.C. (1994). Structure and Chemistry of the Apatites and Other Calcium Orthophosphates. Elsevier, Amsterdam, 387 p. ISBN 0-444-81582-1.

Ellis, D.I. \& Goodacre, R. (2006) Metabolic fingerprinting in disease diagnosis: Biomedical applications of infrared and Raman spectroscopy. Analyst, 131, 875-885.

English, J.A., Scolack, C.A., \& Ellinger F. (1954) Oral manifestations of ionizing radiation II. Effect of $200 \mathrm{kV}$. X-Ray on rat incisor teeth when administered locally to the head in the 1,500 R dose range. J. Dent Res., 33, 377-388.

Geller J.H. (1958). Metabolism significance of collagen in tooth structure. J. Dental Res., 4, 276-279.

Kazanci, M., Roschger P., Paschalis E.P., Klaushofer K., \& Fratzl P. (2006) Bone osteonal tissues by Raman spectral mapping: Orientation-composition. J. Struct. Biol. 156, 489-496.

Le Geros R.Z. (1981). Apatites in biological systems. Prog. Crystal Growth Charact. 4, 1-5.

Le Geros R.Z. (1991). Calcium Phosphates in Oral Biology and Medicine. Ed. by H. Myers (S. Karger, Basel), New York, N.Y., 200 p., ISBN 978-3-8055-5236-3

Leus P.A., Dmitrieva N.I., \& Beliasova L.V. (1998). Dental health of Chernobyl power station accident liquidators, in: The Second Conf. Further Medical Consequents of Chernobyl Power Station Accident, Ukraine, Kiev, May 1998, p.98 (in Russian).

Morris, M.D., \& Finney, W.F. (2004) Recent developments in Raman and infrared spectroscopy and imaging of bone tissue. Spectroscopy, 18, 155-159.

Neuberger A. (1956). Metabolism of collagen under normal conditions. Chem. Abstr. 50, 12252f.

Nelson, D.G.A. \& Williams B.E. (1982) Low-temperature laser Raman spectroscopy of synthetic carbonated apatites and dental enamel. Australian Journal of Chemistry, 35, 715-727.

Marcovic M., Fowler, B.O., \& Tung, M.S. (2004). Preparation and comprehensive characterization of a calcium hydroxyapatite reference material. NIST Journ. Research, 109 (6), 553-568.

Revenok B.A. (1998) Oral cavity health of people which took part in liquidation of Chernobyl accident consequences, in: The Second international Conf. Further Medical Consequents of Chernobyl Power Station Accident, Kiev, Ukraine May 1998, p.352 (in Russian).

Ross, H. Michael, Gordon, I. Kaye, \& Wojciech P. (2003) Histology: Text and Atlas. Lippincott Williams and Wilkins, 4th edition, 875 p., ISBN-13: 978-0683302424

Sobkowiak, E.M., Beetke, E., Bienengräber, V., Held, M., \& Kittner K.H. (1977) The problem of damage to the tooth germ by ionizing radiation (in Germ). Zahn Mund Kieferheilkd Zentralbl., 65 (1), 19-24.

Ten Cate, A.R. (1998). Oral Histology: Development, Structure, And Function. Saint Louis: Mosby-Year Book, 5th edition. ISBN 0-8151-2952-1

Tsuda, H. \& Arends, J. (1994). Orientational Micro-Raman Spectroscopy on Hydroxyapatite Single Crystals and Human Enamel Crystallites. J.Dent Res , 73, 1703-1710.

Zhang, X., Li Y.J., Wang S.L., \& Xie J.Y. (2004) Effect of irradiation on tooth hard tissue and its resistance to acid (in Chin.) Zhonghua Kou Oiang Yi Xue Za Zhi, 39, 463-466. 


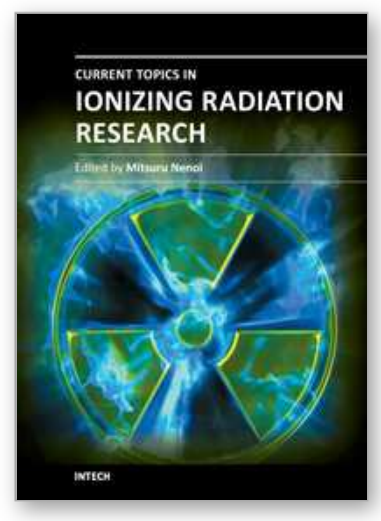

\author{
Current Topics in lonizing Radiation Research \\ Edited by Dr. Mitsuru Nenoi
}

ISBN 978-953-51-0196-3

Hard cover, 840 pages

Publisher InTech

Published online 12, February, 2012

Published in print edition February, 2012

Since the discovery of $X$ rays by Roentgen in 1895 , the ionizing radiation has been extensively utilized in a variety of medical and industrial applications. However people have shortly recognized its harmful aspects through inadvertent uses. Subsequently people experienced nuclear power plant accidents in Chernobyl and Fukushima, which taught us that the risk of ionizing radiation is closely and seriously involved in the modern society. In this circumstance, it becomes increasingly important that more scientists, engineers and students get familiar with ionizing radiation research regardless of the research field they are working. Based on this idea, the book "Current Topics in lonizing Radiation Research" was designed to overview the recent achievements in ionizing radiation research including biological effects, medical uses and principles of radiation measurement.

\title{
How to reference
}

In order to correctly reference this scholarly work, feel free to copy and paste the following:

L. A. Darchuk, L. V. Zaverbna, A. Worobiec and R. Van Grieken (2012). Molecular Spectroscopy Study of Human Tooth Tissues Affected by High Dose of External lonizing Radiation (Caused by Nuclear Catastrophe of Chernobyl Plant), Current Topics in Ionizing Radiation Research, Dr. Mitsuru Nenoi (Ed.), ISBN: 978-95351-0196-3, InTech, Available from: http://www.intechopen.com/books/current-topics-in-ionizing-radiationresearch/molecular-spectroscopy-study-of-human-tooth-tissues-affected-by-high-dose-of-external-ionizingradia

\section{INTECH}

open science | open minds

\section{InTech Europe}

University Campus STeP Ri

Slavka Krautzeka 83/A

51000 Rijeka, Croatia

Phone: +385 (51) 770447

Fax: +385 (51) 686166

www.intechopen.com

\section{InTech China}

Unit 405, Office Block, Hotel Equatorial Shanghai

No.65, Yan An Road (West), Shanghai, 200040, China

中国上海市延安西路65号上海国际贵都大饭店办公楼 405 单元

Phone: +86-21-62489820

Fax: $+86-21-62489821$ 
(C) 2012 The Author(s). Licensee IntechOpen. This is an open access article distributed under the terms of the Creative Commons Attribution 3.0 License, which permits unrestricted use, distribution, and reproduction in any medium, provided the original work is properly cited. 